\title{
Through the Lens of Mirza of Delhi: The Debbas Album of Early-Twentieth-Century Photographs of Pilgrimage Sites in Mecca and Medina
}

\section{Citation}

Asani, Ali, and Carney E. S. Gavin. 1998. Through the lens of Mirza of Delhi: The Debbas album of early-twentieth-century photographs of pilgrimage sites in Mecca and Medina. Muqarnas 15: 178-199.

\section{Published Version}

http://archnet.org/library/documents/one-document.jsp?document_id=8951

\section{Permanent link}

http://nrs.harvard.edu/urn-3:HUL.InstRepos:3202347

\section{Terms of Use}

This article was downloaded from Harvard University's DASH repository, and is made available under the terms and conditions applicable to Other Posted Material, as set forth at http:// nrs.harvard.edu/urn-3:HUL.InstRepos:dash.current.terms-of-use\#LAA

\section{Share Your Story}

The Harvard community has made this article openly available.

Please share how this access benefits you. Submit a story.

\section{Accessibility}




\section{THROUGH THE LENS OF MIRZA OF DELHI: THE DEBBAS ALBUM OF EARLY-TWENTIETH-CENTURY PHOTOGRAPHS OF PILGRIMAGE SITES IN MECCA AND MEDINA}

\author{
"Looking at the House of God is worship..." \\ Caption beneath a pholograph of the $\mathrm{Ka}^{\mathrm{c}} \mathrm{ba}^{1}$
}

Bafflingly elusive, despite careful efforts to protect their expert camerawork from piracy, H. A. Mirza and Sons, photographers of Chandni Chowk, Delhi, are today known to us only through fourteen views of Mecca and Medina. These have survived in two starkly contrasting formats: as very simple picture postcards, some with Urdu captions written in white ink across the bottom of each photograph, and as large prints displayed in an opulent leather-bound album of which there are only two extant copies. The prints reproduced here as figures I-12 are from the Mirza album belonging to Fouad C. Debbas of Beirut (subsequently referred to as the Debbas Mirza album); the other copy is preserved in the British Library Oriental and India Office Collections. The twelve photographs in the Debbas album are bound so that five scenes near or in Mecca (figs. 1-5) are followed by seven scenes near or in Medina (figs. 6-12). The British Library album (OIOC photographs 174) includes thirteen photographs (numbered 138-150), plus an additional photograph depicting an exterior view of the Haram at Medina; it is bound in a totally different sequence with no discernible pattern. Using the numbers for the figures used here in the Debbas sequence, the sequence in which British Library photographs were bound into their album is nos. 7, 12, 1, 13 (13 is not in the Debbas album), 5, 2, 9, 6, 3, 10, 4, I1 and 8 . Each photograph in the Dcbbas Mirza album is framed by a blue tinted window mat and identified with a title at the center top. On either side are effusive verses of Urdu poetry and contemplative commentaries splendidly hand-calligraphed in brilliant crimson ink. At the bottom, approximately in the center, appears the name of the publisher.

The Debbas Mirza photographs use the gelatin/ silver print process; they measure $8.5 \times 12$ inches (21.5 $\times 30 \mathrm{~cm}$ ) and show evidence of toning. They still retain a high gloss finish. The outer dimensions of their mats are $13.75 \times 17.75$ inches $(34.5 \times 43 \mathrm{~cm})$; their window openings measure $8 \times 10.8$ inches $(21.5 \times 30$ $\mathrm{cm})$. The commentaries are harmoniously handwritten inside mechanically printed borders with double lines of purple ink which intersect to form tiny crosslike designs. A printing establishment seems to have signed its work with the intials K. P. I. at the lower left. Centered above the text the printer placed an elegant star within a crescent, much like the symbol of the Ottoman Empire. However, the star in Mirza's crescent dramatically alludes to his Indian roots: his tiny five-pointed star has been adorned with (25) rays which form a downward pointing pentagon around the star. The symbol must have been meant to evoke the Star of the Order of the Indian Empire which displays 35 rays extending from the center of a fivepointed Star of India so that its outline also forms a pentagon pointing downward.

Some of the Debbas Mirza prints have faded and yellowed over time, perhaps because of insufficient washing as well as the proximity of sulfur in the cardboard mat and adhesives. Stamped in red ink directly onto the emulsion of each print is a message of registration to protect against unauthorized copying. Similar notices of registration in Urdu are stamped with blue ink and also pasted to the back of each photograph: "These pictures of Mecca and Medina [are presented here with] all rights reserved; no one may copy these under penalty of punishment. H. A. Mirza \& Sons, Photographers, Chandni Chowk, Delhi."

H. A. Mirza published these photographs in Delhi on 15 October 1907 (see notations in English on the reverse of each mount in the British Library OIOC album). No earlier publication of Mirza's photographs has yet turned up, but evidence from Holland (1908) and Paris (1912) indicates that Mirza's camera work, even in picture-postcard format, had caught the eye 
of diplomats in Jedda. On 17 May 1908, only eight months after its publication in Delhi, postcards depicting Mirza's photograph of Arafat (fig. 2) were sent by Scheltema, Holland's consul in Jedda, to C. Snouck Hurgronje, the renowned Dutch Orientalist in Leiden. At least six Mirza photographs (figs. 2, 3, 4, 6, 9, and 12) were found printed on postcards that once belonged to the collections of Het Oosters Instituut in Leiden. They are currently being incorporated into the Library of the Rijksuniversiteit in Leiden together with other collections assembled by Snouck Hurgronje, notably photographs and sound recordings from the Hijaz. The research team of the Archives for Historical Documentation (AHD) in Brighton, Massachusetts. first sorted and identified these postcards in 1983, assigning them tentatively the designations L/OI:D 15-22, 25, and 26. Several seemed associated with Netherlands Consul Wolff and a packet of documentation which he had sent from Jedda in 1913. Some (especially D15 and 17, both showing Arafat, fig. 2) clearly had been received on " $17 / 5 / 08$ " from Wolff's predecessor Consul Scheltema, who himself printed his own photographs in postcard format. The clue which led the AHD team to the recovery of the earliest wax cylinder sound recordings from Arabia was a Scheltema postcard which had been mailed from Jedda in 1909.?

Four years later, in 1912, H. Kazem Zadeh, an inspector at the Persian consulate in Jedda, used Mirza's photographs of burial sites (figs. 4, 10, and 11) and Medina's fortifications flanking the Anbari Gate to illustrate the French publication of an account of his pilgrimage to Islam's holy cities. ${ }^{3}$ Three Mirza photographs (corresponding to our figs. 11, 10 and 4) are reproduced as the frontispiece and the plates facing pages 8 and 34 respectively. A fourth illustration (which Zadeh reproduces facing p. 18) shows "les murs de Medina et la porte Anbari." A strip across the foreground declares this view (the only one not found in either Mirza album) to be the work of H. A. Mirza and Sons of Delhi. Similar caption strips are found across Leiden postcards D19 and 20 which suggests that Zadeh brought Mirza photographs in postcard format for Leroux in Paris to reproduce. Aside from that solitary strip, however, nowhere is Mirza's work acknowledged in Zadeh's text.

The Mirza album contains views of various sites in al-Haramayn of religious significance to Muslims, but most of its illustrations depicted scenes of particular interest to Muslim pilgrims from the Indian subcon- tinent. Among them are the cemetery of al-Baqi (fig. 11), where the Prophet Muhammad's family and companions are buried, ${ }^{4}$ and the tomb of Amir Hamza (fig. 10), the uncle of the Prophet and hero of a folk epic widely read by Urdu speakers on the subcontinent. $^{5}$

The Urdu commentaries accompanying the Mirza prints also point out details which would be especially relevant to South Asian pilgrims, such as the prayer area in the sanctuary of the $\mathrm{Ka}{ }^{\circ} \mathrm{ba}$ designated for Muslims of the Hanafi rite to which most South Asian Muslims of the Sunni persuasion adhere. One of the photographs (fig. 7) shows the tents of the Ottoman Turkish troops; at first glance this may seem incongruous in an album on sacred places, but its inclusion is not so surprising given that for several centuries political ascendancy of Muslims (and Islam) in South Asia was associated with dynasties of PersoTurkish ancestry, the last of whom, the Mughals, had been formally overthrown in 1857. Almost fifty years later, at the time of the album's publication, the Turks continued to be revered and highly esteemed among the subcontinent's Muslims for their military virtues and conquests in the name of Islam. Until the abolition of the Ottoman caliphate in 1924, many Indian Muslims regarded the Ottoman sultan as the titular head of the entire Islamic world.

Mirza's photographs contain timeless scenes of pilgrims and pilgrimage sites, but they also provide several architectural views which permit us to study the changes al-Haramayn's urban features underwent in the quarter-century that elapsed between the very first photographic records ever made in Mecca and Medina and the publication of Mirza's photo albums. In that time, surprisingly little had been built in the holy cities; three examples serve to illustrate the usefulness of Mirza's record for urban studies:

1. In Mirza's panorama of Medina (fig. 9) the only substantial architectural change that can be detected from a comparison with the 1880 photorecord by Colonel M. Sadiq Bey, ${ }^{b}$ is the block of buildings added outside and to the left of the Great Gateway. The new buildings were executed in a local style with characteristic second-story mushrabbiyas (referred to as roshan in the Hijaz) facing the desolate areas outside Medina's city wall. Colonel Sadiq's photographs of Mecca had featured three new buildings in 1880 , each of which had been constructed in variations of the imperial Ottoman Beaux-Arts style. The three buildings were a relatively simple police headquarters, a printing plant, and an elaborate government house 
called the Hamidiyya after the Ottoman Sultan Abdul Hamid II. Could the use of only local building styles suggest some weakening of imperial self-consciousness shortly before the political reforms of 1909 ?

2. Mirza's view above the Ka'ba in Mecca (fig. 1) may be compared with the left-hand portion of the three-part panorama of Mecca made by al-Sayyid Abd al-Ghaffar between 1885 and 1889 . This view was published in 1889 by Snouck Hurgronje without mentioning the name of the photographer. Mirza's 1907 photograph shows that the small minaret in the foreground had been refurbished during the intervening decades: its stonework was carefully repointed and its original metal finial seems to have been removed. Otherwise, little had changed near the Haram. On the upper-right hill crest, however, several large buildings in an austere local style had been constructed along the ridge to constitute the only discernible additions to $\mathrm{Mec}-$ ca's skyline.

3. Mirza's photograph of Mina (fig. 3) depicts the dazzingly white expanse of the al-Khayf Mosque which no longer stands today. There is evidence of destruction, perhaps fire damage, at the top of a three-story building in front and to the right of the iwan-like entryway. A pre-1889 photograph ${ }^{7}$ has captured this three-story building intact, yet its forms, proportions, and surface treatments indicate that this tall structure had been added later outside the original mosque complex, which dates back to Qaitbay.

Although today the Mirza prints serve as an invaluable historical record of architectural change, the original motivation behind their production was clearly religious. The tradition of depicting Islam's two holiest cities in pietistic contexts reaches back at least five centuries, manifested as topographic sketches or schematic representations in various documents, such as illuminated haji certificates, pilgrim guidebooks, and plans of encampments. In addition, pictures of religious shrines in the two cities were also used to decorate the walls of houses and palaces. ${ }^{8}$ The principal concern in these topographic illustrations was to show clearly and distinctly the various details of religious significance to a pilgrim or to describe the general layout of the holy sites to those unable to participate in the hajj. Often the perspective used in drawing a monument like the $\mathrm{Ka}^{\mathrm{C}} \mathrm{ba}$ in Mecca or the mosque of the Prophet in Medina allowed for different methods of representation, such as a plan and elevation, to be combined in one picture. ${ }^{9}$ Further to assist the pilgrim in identifying and locating the various places of religious interest, the sites would frequently be indi- cated by calligraphic annotations. The theologically based disapproval of figural representation meant that as a rule no human beings or other lixing creatures were depicted in these sketches.

In this long tradition, the Mirza albums play a significant role: Mirza's pictures are the first datable use of photographs of the holy places explicitly published to assist Muslims in prayerful contemplation. ${ }^{10}$ Though they are not the earliest surviving photographs of Mecca and Medina, ${ }^{11}$ their use in a devotional context punctuates a whole new phase in transnational communication. The advent of photography made available for Muslims a revolutionary way of depicting their holy places with much greater immediacy, for photographs could visually transport viewers to the actual sites. Although photography, by virtue of its ability to capture true-to-life images, continues to be controversial among some religious scholars, ${ }^{12}$ many Muslims have readily embraced the use of the new medium.

The uniqueness of the Mirza photographs also stems from the devotional commentaries in Urdu prose and poetry arranged along their borders. Admittedly, these inscriptions are not unusual in content they contain the same information found in traditional pilgrimage guides - but their marginal location does suggest their role in guiding the viewer to a fuller appreciation of the religious and spiritual significance of the central image. Portions of several commentaries, while directing attention to the images themselves, also suggest to potential pilgrims what they ought to feel. ${ }^{13}$ Thus the poem above the picture of the mosque of Quba (fig. 8) invites the viewer to

\footnotetext{
Come, have a look - this is that mosque of Quba

which is the prayer place of the essence of the beloved

of Divine Grandeur [i.e. the Prophet Muhammad]

Look, the Holy Qur'an praises it. ...
}

The verses above the picture of the Prophet's mosque (fig. 12) declare:

The sanctuary of the mosque of the messenger of God

which the world yearns to see:

A garden of Paradise and the mausoleum of the Prophet;

If you must see it, here is its image.

Similarly, the photograph of the city of Medina (fig. 9) contains the following caption in verse above it: 
It is fitting if you place on the mirror of the heart The photo of the Medina of the king of the two worlds.

In all these examples, the viewer is clearly being led by the text to contemplate or meditate on the images so as to internalize them. These comments suggest that H. A. Mirza and Sons, Photographers, were deliberately attempting to harness the newly developed art of photography and its power to capture realistic images in the service of Islamic piety. ${ }^{14}$

Frequently, photographs in guidebooks are accompanied by a commentary or verses of religious poetry that clearly indicate that the very act of looking at the photographs is regarded as an act of piety. Their ability to "transport" viewers to the holy sites takes on an added significance, for immediacy of experience is highly prized by readers. Barbara Metcalf writes in her study of South Asian accounts of the pilgrimage:

Over and over, the successful accounts written in recent decades are praised for making the hajj vivid and present before the reader's eye; the reader identifies with the writer and vicariously lives his experience. Readers' letters prefaced to the publication of Muhammad Riza Ansari's account (1965), for example, praise it for being a veritabie cinema and avow that the reader feels that he has made the haij himself. The text itself serves as the haij. ${ }^{15}$

That photographs in these books are not merely illustrations, but deliberately used to inspire religious emotions and sentiments is best illustrated by a passage from a recent guidebook to the pilgrimage written in Urdu in which the author explains the functions of the photographs in his book:
... [I wanted] the photographs to be arranged so that the pilgrim, once having seen them, can memorize them and when be reaches that place. it does not appear foreign to him. ... And he who is not granted the good fortune of visiting the House of God, by seeing a vague reflection of it in the photograph of the House of God, can arouse freshness in his soul. Such beautiful closeups have been taken ... that the viewer feels that he is actually sitting and standing at that place. . . These photographs show every place that is necessary for the performance of the pilgrimage. . ${ }^{16}$

The twelve photographs from the Debbas Mirza album follow, numbered in the sequence in which they are bound in the album, with translations of the accompanying Urdu text. The translations of the verses of poetry on either side of the title appear first, followed by the descriptive text in the margins around the photograph. As they demonstrate, the Mirza photographic album, with its contemplative annotations, was for its time unique in its intention to serve both as a visual guide to Islam's holy places and to excite and inspire the religious imagination of the pious. The album represents the earliest prototype of the pietistic use of Mecca and Medina photographs that are now so common in pilgrimage guidebooks published in the Urdu language in contemporary South Asia.

\section{Harvard University \\ Cambridge, Mass.}

Archives for Historical Documentation

Brighton, Mass. 


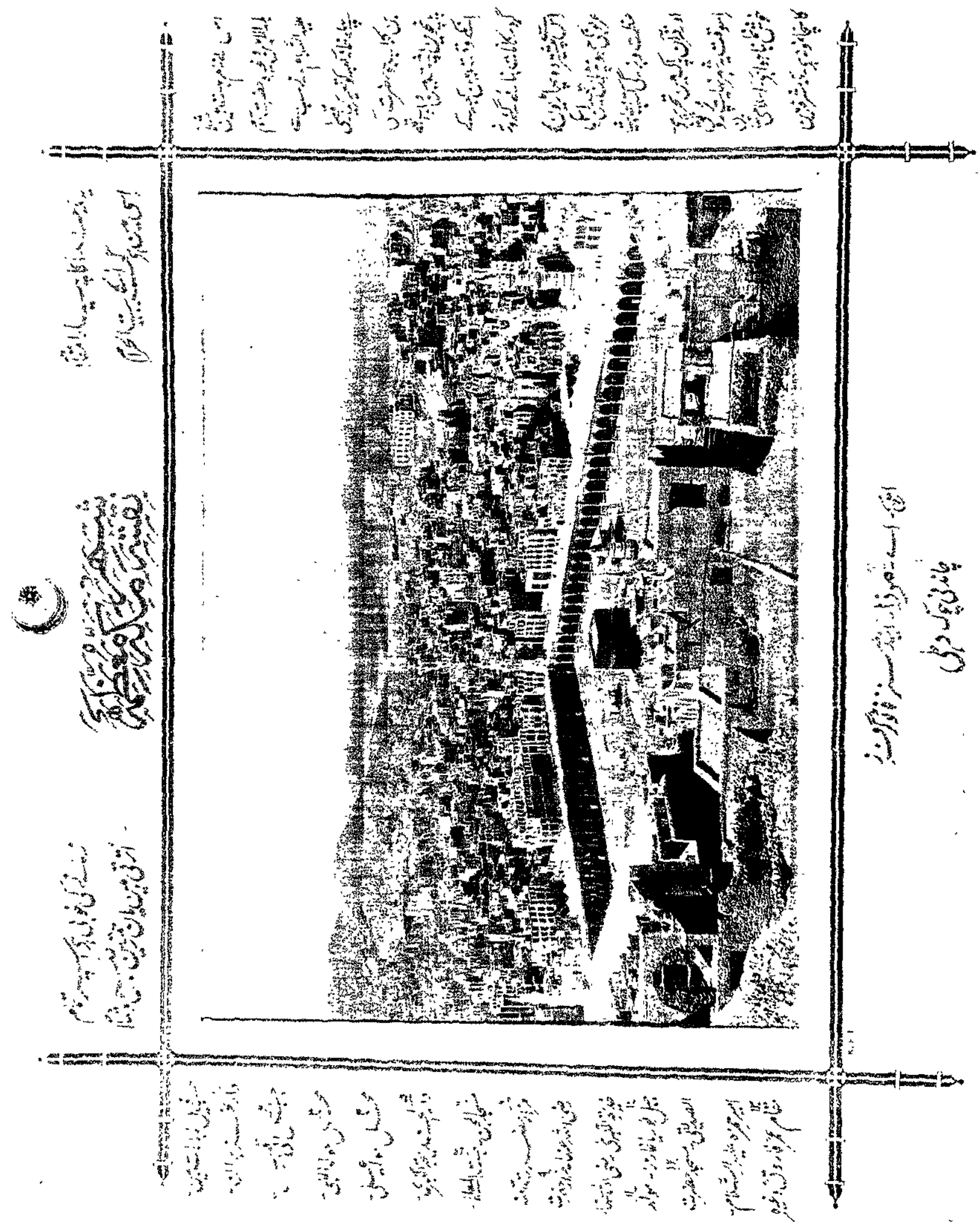




\section{Picture of the City of Mecca the Great}

This is Mecca, the beloved residence of God. Within it is His house, the bait al-haram. All the virtues of the world are perfected in it; Blessings from on high descend here day and night.

It has many names such as balad al-amin ${ }^{\mathrm{a}}$ and so on. Adam, peace be upon him, was the first to build the $\mathrm{Ka}{ }^{\mathrm{C}} \mathrm{ba}$. The surrounding buildings were built during the time of Qasa ibn Kulab, the Prophet's paternal grandfather of the fifth generation. Before this [time], there were only the small huts of Arabs on the two hills. Its greatness is recorded in the books of tradition (hadith) and in the holy Qur'an. At present this city has become extremely graceful and beautiful. It is a veritable example of Islamic glory. In the noble Mecca, the places of pilgrimages are as follows:

(1) the house of Khuzairan ${ }^{b}$

(2) Mount Abi Qabus ${ }^{c}$

(3) the birthplace of the Prophet

(4) the birthplace of ${ }^{\mathrm{A}} \mathrm{Ali}^{\mathrm{d}}$

(5) the house of Khadija the Great ${ }^{\mathrm{e}}$

(6) the Mosque of the Jinn ${ }^{f}$

(7) the paradise of al-Ma' ala

(8) the mausoleum of Amina, may God be pleased with her ${ }^{\mathrm{h}}$

(9) the mausoleum of Khadija the Great, may God be pleased with her

(10) Mount Nur or the cave of Hira

(11) the birthplace of the "sincere one"I

(12) the mosque of Amir Hamza, ${ }^{k}$ peace be upon him

(13) the residence of 'Umar Faruq'
"The city of the "trustworthy one," i.e., the Prophet Muhammad.

bKhuzairan (Khayzuran), mother of the Abbasid caliphs Musa al-Hadi and Harun al-Rashid, renowned for her refurbishing of the holy places in Mecca, including the birthplace of the Prophet, while she was on plgrimage in 788. She also purchased for use as her own residence the House of Islam, a house where the Prophet used to meet his followers secretly to avoid persecution. This house, which came to be known popularly as the Khayzuran house, became one of the city's most famous landmarks.

cA small mountain to the east of Mecca, the sancticy of which reaches back to pre-Islamic times and is associated with many religious legends. For example, it is at the foot of this mountain that the Prophet Muhammad is believed to have performed the miracle of splitting the moon.

d'Ali ibn Abi Talib (d. 661), cousin and son-in-law of the Prophet.

'Khadija bint Khuwaylid ibn Asad (d. 619), the Prophet's first wife.

'At this mosque, jinn are believed to have overheard Muhammad while he recited the Qur'an and converted to Islam. It was here that the seventy-second chapter of the Qur'an, which alludes to this incident, was revealed.

gRenowned cemetery, see fig. 4.

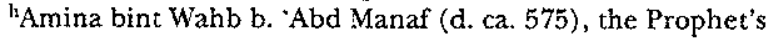
mother.

${ }^{1}$ According to tradition, Muhammad used to retire to this cave to meditate and pray. It is here that he is believed to have received his first revelation from God.

JAl-Siddiq, honorific of Abu Bakr (d. 634), companion and father-in-law of the Prophet and the first Caliph.

kAlso known as Hamza b. 'Abd al-Muttalib (d. 625), the paternal uncle of the Prophet who, after his conversion, became one of the bravest champions of Islam. He lost his life at the battle of Uhud in 625, fighting in a small army of Muslims aganst the Meccans. He is the hero of a romantic popular among the Muslims of South Asia.

${ }^{1}$ Umar ibn al-Khattab (d. 644), the second caliph. 


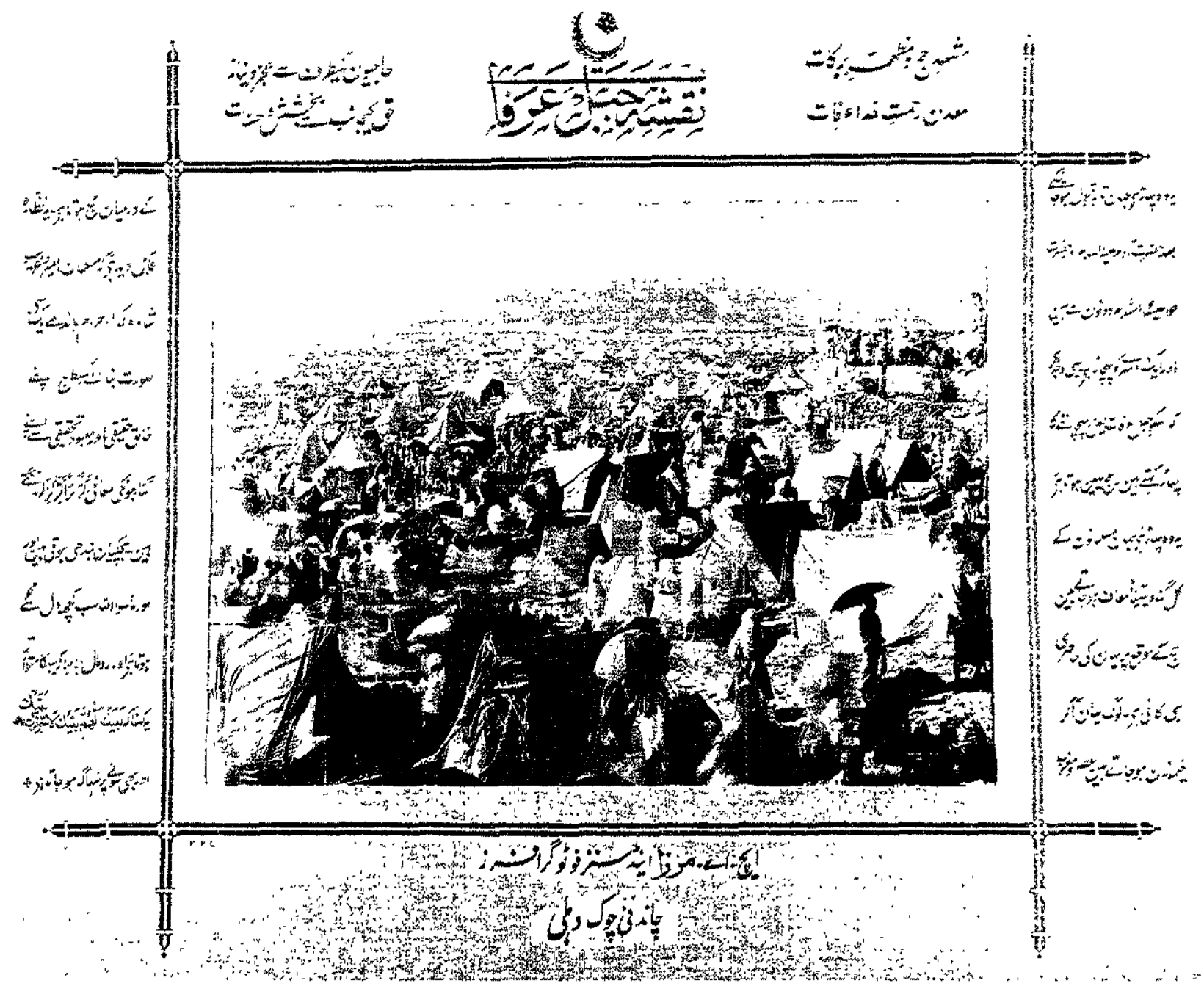

\section{Picture of Mount 'Arafat}

The place of assembly of the hajj and the locus of blessings (barakāt)

'Arafat, the mine of God's mercy;

Submission and supplication from the pilgrims

Beneficence and kindness from God.

This is the mountain where repentance will be accepted. It was here that Adam, blessings be upon him, and Hawa [Eve], blessings be upon her, met and recognized each other - this is the reason why it is called Mount "Arafat, that is, the "mountain of recognition." The [act of] hajj takes place here. This is the mountain where all sins of Muslims are certainly forgiven.
At the time of the hajj, attendance here is quite overwhelming. People come and pitch tents, with the [act of] hajj occurring between the afternoon and sunset prayers. It is indeed a sight worth seeing - the manner in which Muslims, rich and poor, king and beggar, all wearing the inrām and looking alike, beseechingly asking for forgiveness of their sins from the true Creator and the real object of worship. The sobbing is convulsive and everything other than God is obliterated from the heart. Everyone is continually saying, while waving a handkerchief, "O Lord I am standing at Your service, You who are without equal, I am standing at Your service." On retiring to sleep, there is mystical happiness. 


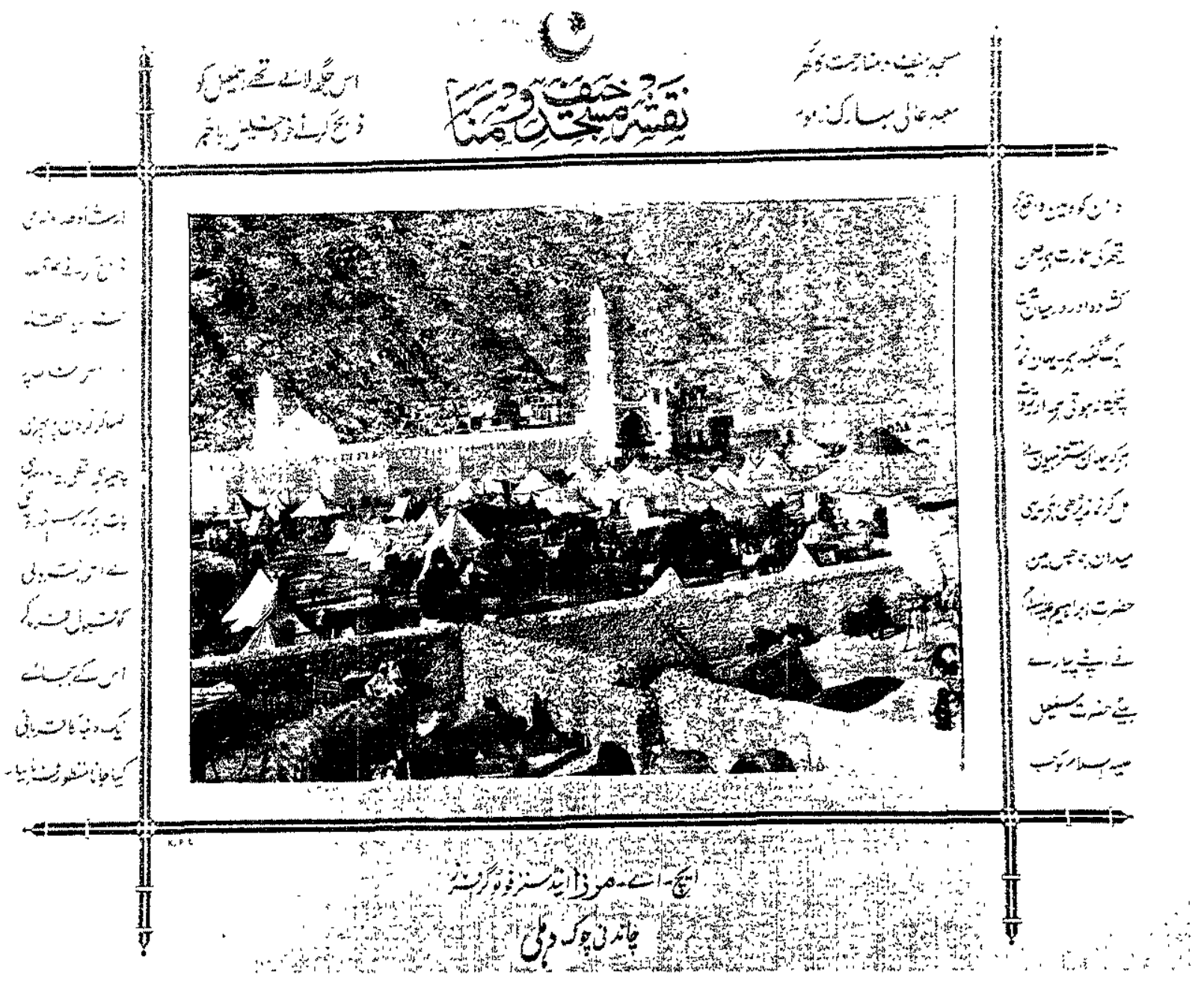

3. Picture of the Mosque of Khaif and Mina (Muna)

The mosque of Khaif and Mina is the house of mercy

The eminent, blessed, and famous place of worship.

The wise friend of God [i.e., Abraham] himself brought for sacrifice to this place, Isma il

Located at the foot of the mountain, it is a building of stone. It has an open courtyard in the middle of which is a domed building. Here the ritual prayer consists of five cycles. There is a tradition that most prophets have assembled here and prayed. This is the very field where Abraham, blessings be upon him, had intended to sacrifice his beloved son Isma'il in accordance with divine command. It is on this ground that he had him [Isma ${ }^{c}$ il] lie down and stroked his neck with a knife. However, God the merciful, having accepted this sacrifice sanctioned that a ram be sacrificed instead. 


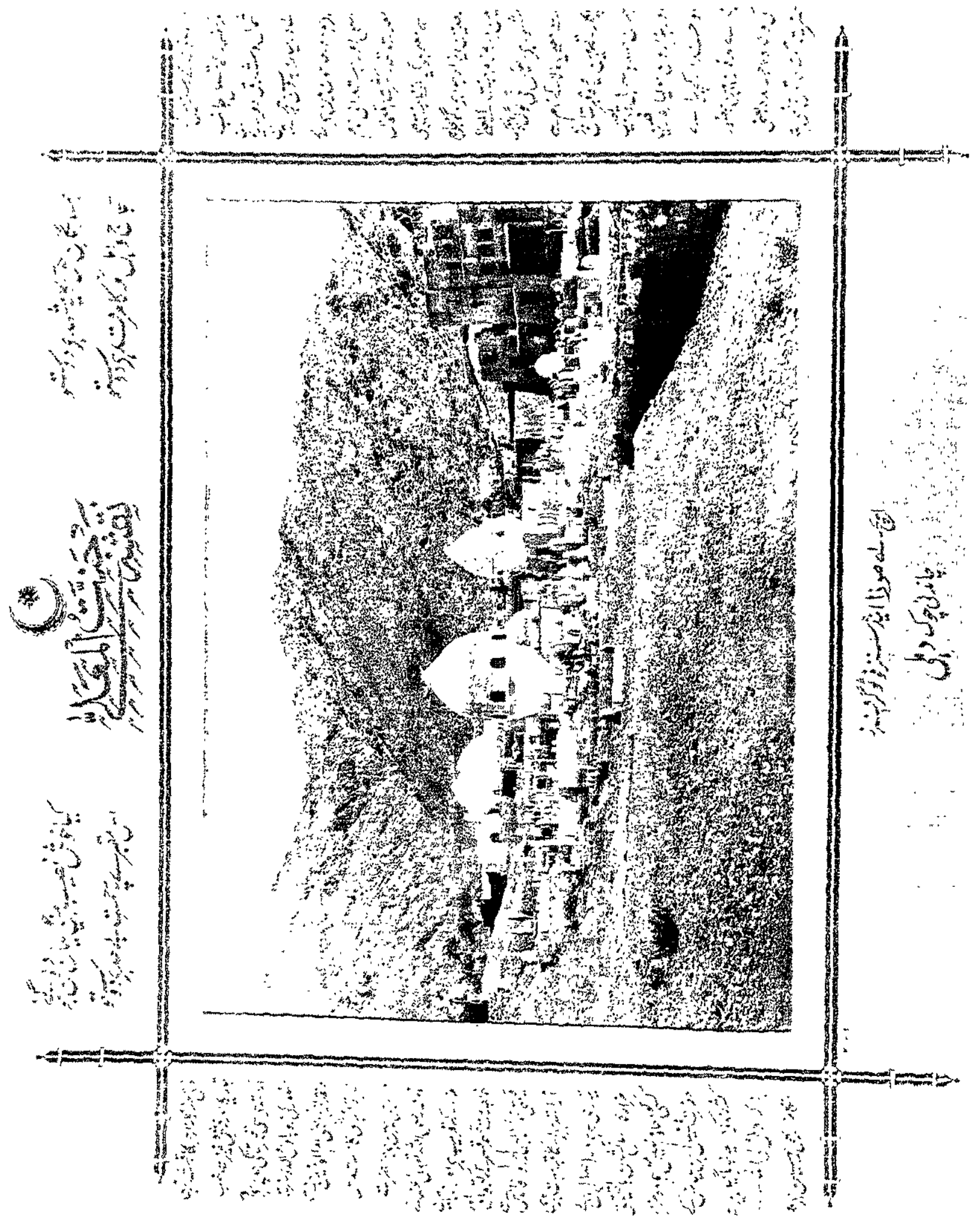




\section{Picture of the Paradise of al-Ma'ala}

Friends, this is the burial place of the neighbors of God $^{\mathrm{m}}$

Friends, this is the resting place of the pilgrims and the people of Mecca.

How fortunate are those who have been buried here.

Friends, on this cemetery is the infinite mercy [of God]

This vast cemetery on the road to Mina and 'Arafat, between two mountains adjoining the honorable city of Mecca to the north and east, contains two divisions. Its original and former name was Ma'alat. From frequency of use it became Ma'ala. The word jannat (paradise) was added later. In the parlance of the pilgrims its popular name is the "paradise of al-Ma'ala" ["the lofty paradise"]; the Meccans, however, still call it Ma'ala or Mala. This is the cemetery in which are buried hundreds of companions of the Prophet and the followers [i.e., the generations after the companions], thousands of enlightened friends of God [saints], and the beloved servants of God. The mausoleum of the Prophet's glorious mother, the Lady Amina, may God be pleased with her, located at the boundary of this cemetery is well adorned with great splendor, carpets, and so on. The holy mausoleum of the Prophet's first wife, the mother of Fatima, the resplendent, and the mother of believers, the Lady Khadija the Great, is also here. It is near the mausoleum of the Lady Amina, may God be pleased with her, and is decorated with various kinds of beautiful inscriptions, valuable and elegant arabesques, and lanterns. Its dome is of great splendor. In reality, nobody knows with certainty the real location of her tomb. The existing mausoleum was built by Fuzail ibn 'Iyaz on the basis of an inspiration. This perfect man was a saint and his mausoleum is also here.

mThe term "neighbors of God" is used to refer to the residents of Mecca as they live in the neighborhood of the Ka"ba or "House of God." Similarly, the inhabitants of Medina are known as the "neighbors of the Prophet." 


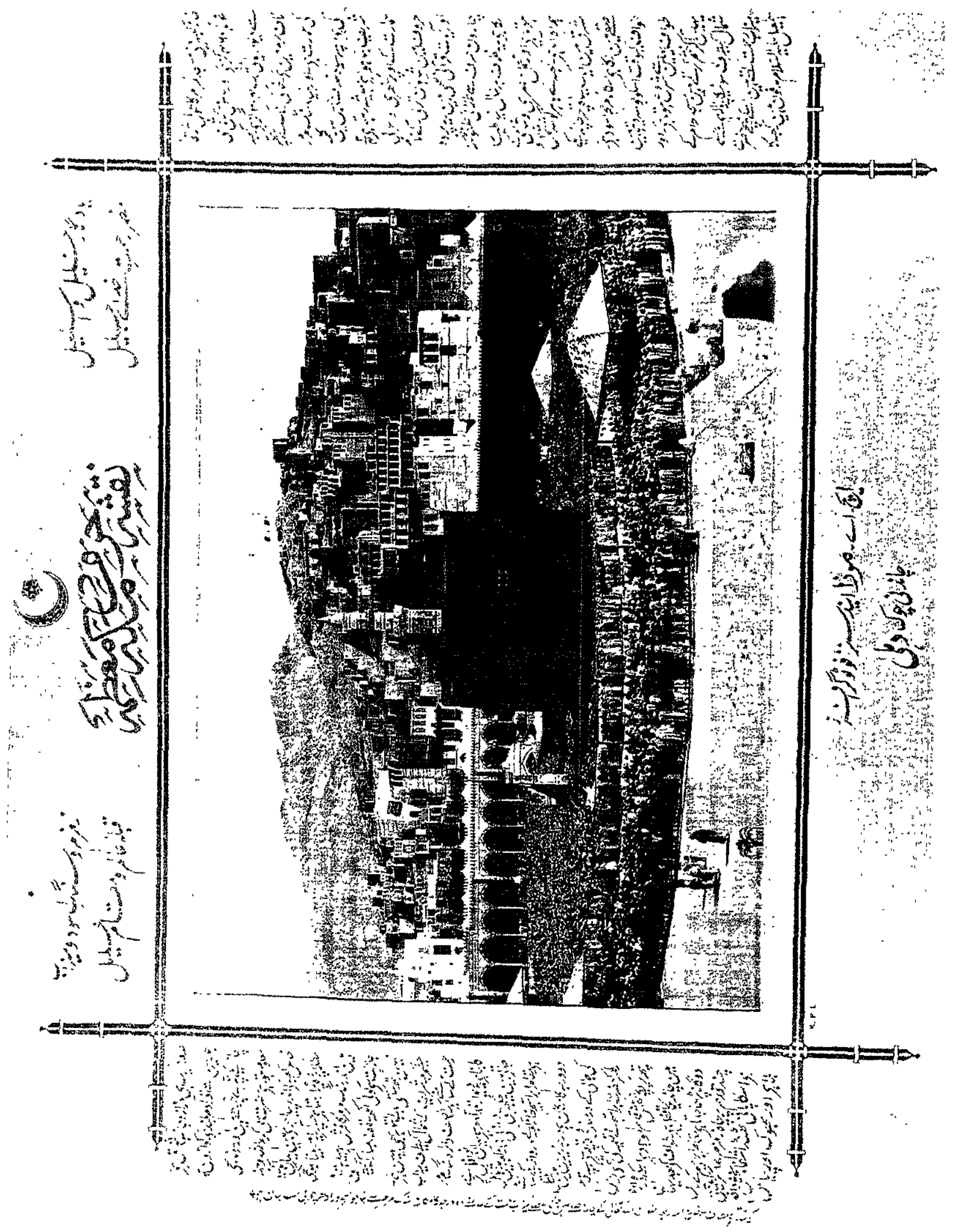




\section{Picture of the Sanctuary of Mecca the Great}

Memorial of Khalil [Abraham] and Ismacil

The place of manifestation of the mercy of God, the glorious;

Zamzam, the black stone, and the waterspout

The qibla of the world, the residence of Khalil

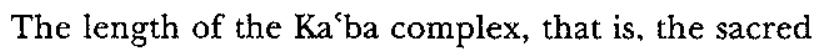
mosque, is 460 yards from east to west and the breadth from the [northern] Syrian corner to the [southern] Yemeni wall is 304 yards. The $\mathrm{Ka}^{\mathrm{c}} \mathrm{ba}$ is in the center of the sanctuary. It is a building of dust-colored stone with marble foundations. Over it lies perpetually a black cover into which the noble confession of the faith has been woven. Three-quarters of the way up the building, written in gold Arabic letters, are the names of the Turkish [i.e., Ottoman] kings and verses from the Qur'an. This cover is attached on all four sides to golden rings. The cover is newly prepared every year and comes [to Mecca] with the Egyptian and Syrian ceremonial litter (mahmal). On the outside of the $\mathrm{Ka}{ }^{\mathrm{C}} \mathrm{ba}$, on the northeast corner, set in a silver ring, is a black stone which is called hajaru'l-aswad. At the time of the circumabulation, they [the pilgrims] kiss it. The circumambulation begins here, and they [the pilgrims] complete it after returning here. On the northern side of the sacred sanctuary is a gold waterspout called mizāb-i rahmat, "the water spout of mercy." Beneath it, [the Prophet] Isma'il is buried.

The one and only door of the $\mathrm{Ka}{ }^{\mathrm{C}} \mathrm{ba}$ is on the east side, at the height of a man above the ground. On its panels, leaves of silver have been mounted and gold also appears. 'Ali, may God ennoble his face, was born inside the $\mathrm{Ka}{ }^{\mathrm{b}} \mathrm{ba}$. Here hangs a gilded curtain on which the âyăt al-baiyināt [the clear and evident Qur'anic verses] are written. Inside, the floor is of marble. Out of fear and awe, no eye can turn itself [i.e., look] towards the blessed ceiling. The door of repentance is also here. On the northern side of the noble $\mathrm{Ka}{ }^{\mathrm{C}} \mathrm{ba}$, across from "the waterspout of mercy" stands the hatim, a semicircular wall made of marble. This wall is as high as a man. Here the supererogatory prayer is recited. This place, too, is contained in the interior of the $\mathrm{Ka}{ }^{\mathrm{b}} \mathrm{ba}$ complex.

The residence of Abraham is a two-storied building opposite the door of the $\mathrm{Ka}^{\mathrm{b}} \mathrm{ba}$ complex. On the first floor, in the middle of the lattice, is the stone on which Abraham had placed his foot during construction. On this stone is found the print of his sacred foot. On the door is a silver lock. After the circumambulation, a prayer of two cycles is recited. A few feet from Abraham's house is the well of Zamzam. It is 87 yards deep. Its water is cold, healing, repels affliction, and quenches thirst and hunger. Beyond the matā $f^{\mathrm{n}}$ are the four prayer places of the imams, ${ }^{\circ}$ may God be pleased with them. The Hanafi prayer place is a two-storied building across from the waterspout of mercy. It is built of marble, and there is wooden canopy here.

"Pavement on which the circumambulation of the Ka'ba is performed.

"That is, the founders of the four orthodox schools of law in Sunni Islam. 


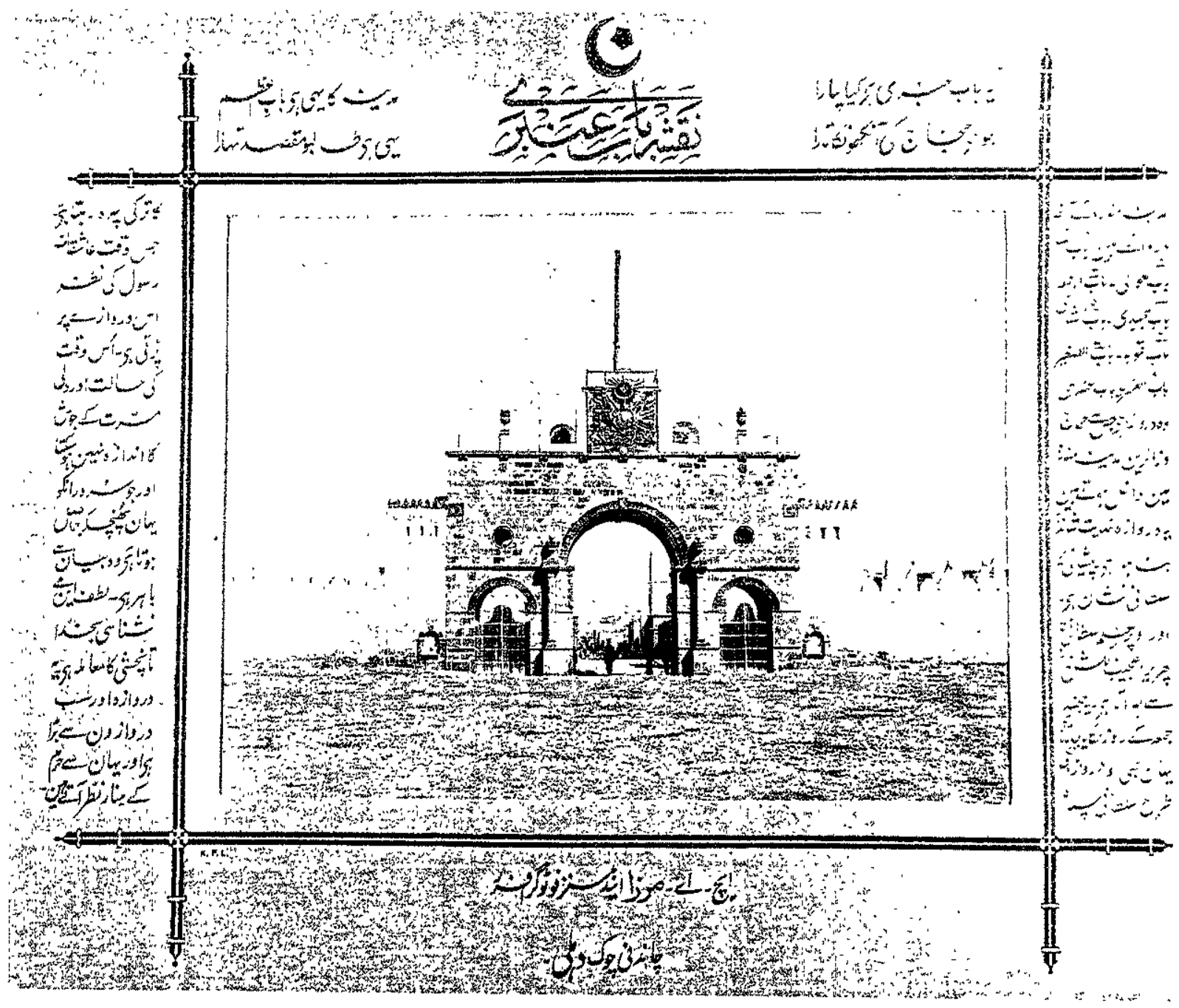

\section{Picture of the Bab 'Anbari}

How beloved is this Bab 'Anbari; The star of the pilgrims' eyes Indeed, it is the main gate of Medina It seeks you and is your goal.

Medina, the radiant, has eight gates:

1. Bab al-Quba

2. Bab al-'Awali

3. Bab al-Jum'a

4. Bab al-Majidi

5. Bab al-Shami

6. Bab al-Qubba

7. Bab al-Saghir

8. Bab al-'Anbar
The Bab 'Anbari is the gate by which pilgrims on the hajj and pilgrims to the tomb of Prophet generally enter Medina the Radiant. This gate has been built with great splendor. On its front is the royal insignia, and above flutters the flag with the royal banner in a wondrously alluring manner. This flag is raised on Fridays. Here, as at the other gates, there is a Turkish [Ottoman] guard from the royal army. It is not possible to describe either the state of the lovers of the Prophet when they see this gate or the rapture of the fervor in their hearts. The joy they experience on reaching here is beyond expression. It is a matter to which the saying, "By God, you will not know the delight of this wine until you taste it," is applicable. This gate is bigger than all the other gates. From here the minarets of the sacred sanctuary are visible. 


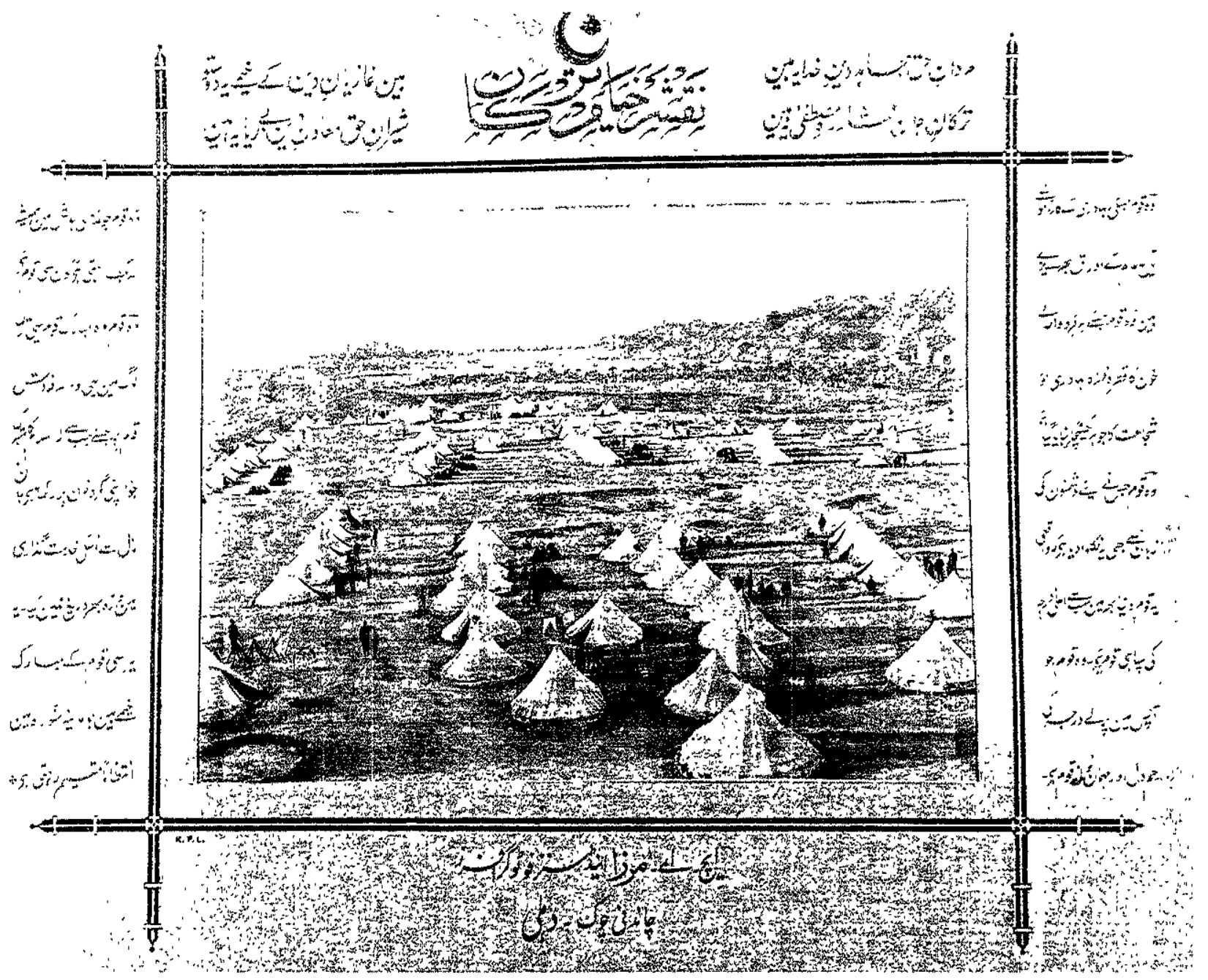

\section{Picture of the Tents of the Turks}

These are the true men of God, the fighters for God's religion;

These are the Turks who sacrificed their lives for the path of the chosen one [i.e., Muhammad]

Friends, these are the tents of the warriors of the faith;

These are the lions of God, the sincere upholders of the faith.

The people, the accounts of whose bravery have filled the pages of world history; the people - each drop of blood that was extracted from every individual and made into a gem of bravery and heroism; the people who made even their enemies utter, "Truly in the entire world, these are a military people of the highest rank"; the people who amongst themselves are a people of the highest degree of kindheartedness and hospitality; the people who in their religious ardor are always ready to sacrifice their life; who are those people? Those people, those blessed people, are these very Turks. They are the self-sacrificing people who, since the time they accepted the blessing of Islam, have served it with spiritual and material commitment, without the slightest hesitation. These are the blessed tents of these people which remain standing in a orderly manner in Medina the Radiant. 


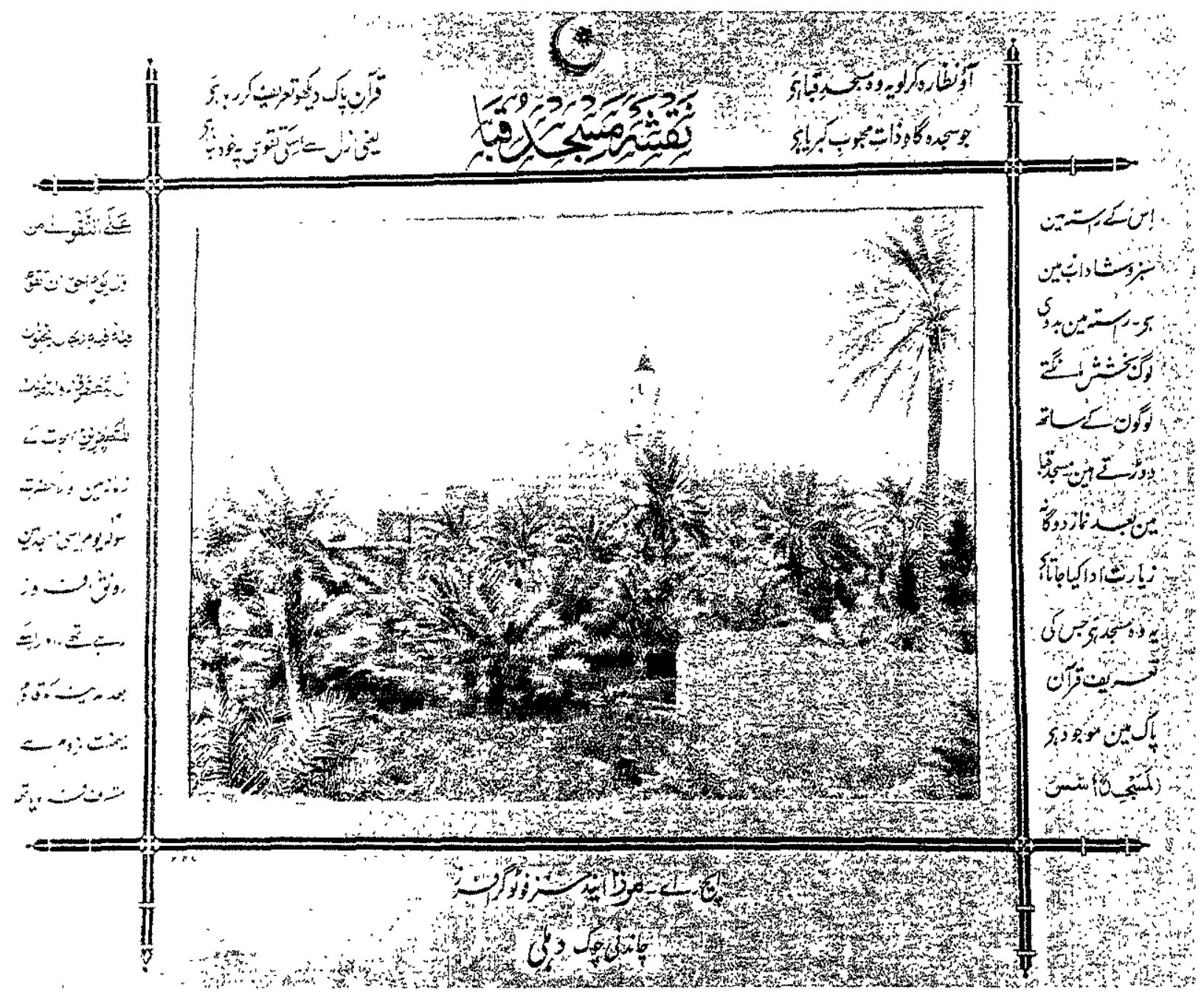

\section{Picture of the Mosque of Quba}

Come, have a look - this is that mosque of Quba which is the prayer place of "the essence of the beloved of Divine Grandeur" the prophet Muhammad $]^{p}$

Look, the holy Qur'an praises it, for

it has been built, since the beginning of creation for its piety.

The road to it runs through green and fertile land. The bedouins run alongside the road begging people for alms. The pilgrimage is performed at the mosque of Quba after a prayer of two cycles. This is the mosque whose praise is found in the holy Qur'an:
"Indeed a mosque founded on the observance of piety from the first day is more deserving that you should stand in it. In it are men who love to purify themselves. And God loves those who purify themselves" [Qur'an 9:108] During the hijra, the Prophet stayed here initially for sixteen days, conferring honor upon it. After this he honored Medina with an arrival that was bound to confer felicity.

PAccording to tradition, this mosque was the first place for public prayer built by the Prophet himself. It is approximately three miles south south-east of Medina. 


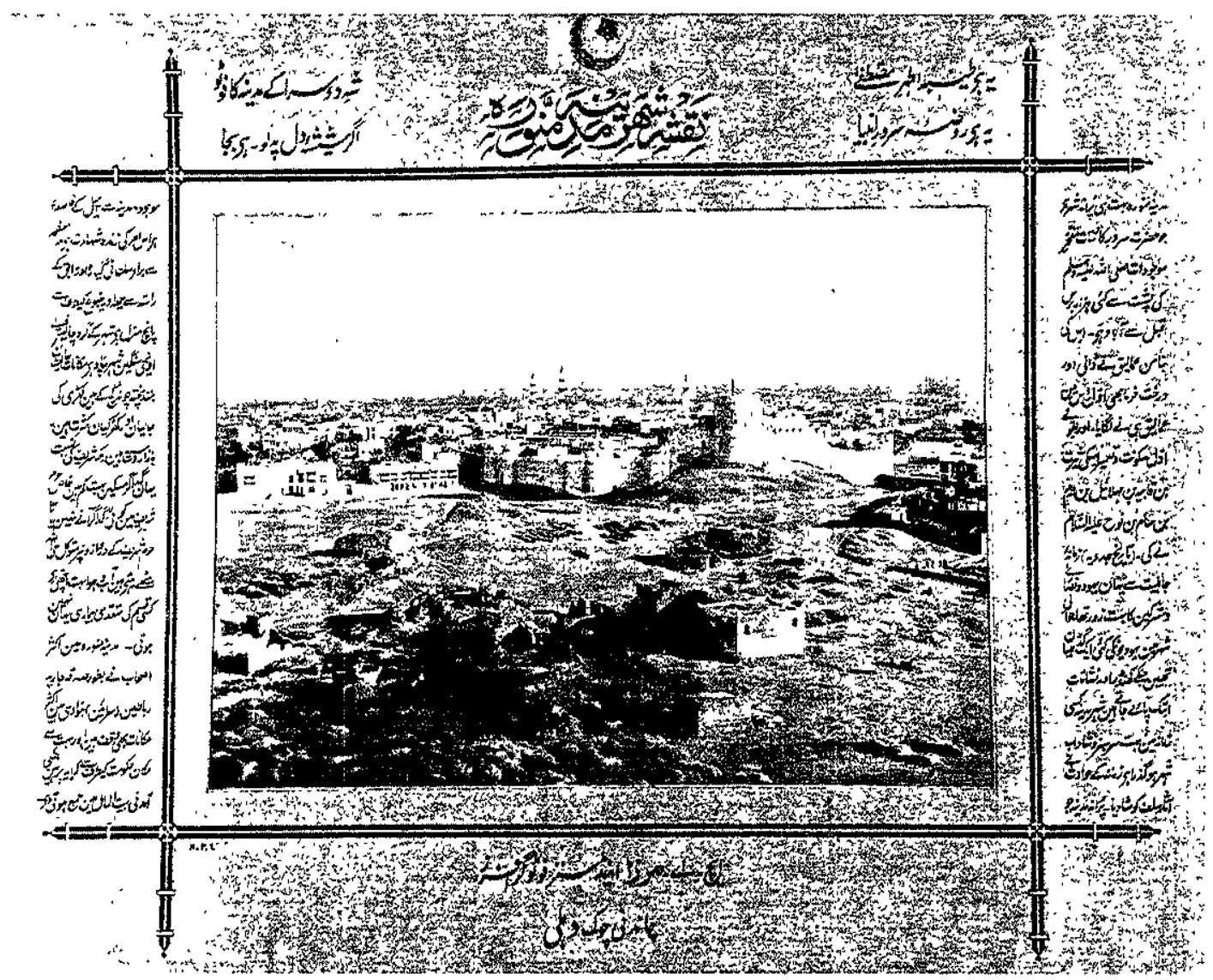

\section{Picture of the City of Medina the Radiant}

This is the most pure Taibah ${ }^{q}$ of the chosen one [i.e., the Prophet Muhammad]

This is the mausoleum of the chief of the prophets It is fitting if you place on the mirror of the heart

The photo of the Medina of the king of the two worlds.

Medina the Radiant is a very old city which had flourished several thousand years before the era of the lord of the universe and the pride of created beings [the Prophet Muhammad], may the peace and blessings of God be upon him. Man Amaliq, who first laid its foundations, was also the first to plant date palms here. According to tradition [the chronicle Tarikh Jidavih?], its first residences and buildings were built by Thayrat [sic] ibn Qabih ibn Mahla'il ibn Aram ibn Sam ibn Nuh, may blessings be upon him. In the era before Islam, the Jews, Christians, and idolators were in great strength here. Around the city there were a few fortresses belonging to the Jews, the ruins and traces of which are still found today. At one time Medina had been a verdant and pleasant city, but the misfortunes of time have obliterated traces of those former days. Old Medina, which is at a distance of three miles from present-day Medina, is a living witness to this fact. By way of the royal highway, it is eleven miles from Mecca the Great; six miles by way of Rabigh and five days journey from the direction of Yanbu. Around the city are stone fortifications that are forty feet high. The buildings are magnificient, tall, solid, and of lime and mortar. Lattices and windows of wood are in abundance. The bazaar is spacious. In comparison to Mecca, the mendicants and beggars are very few. No beggar is allowed to enter the holy sanctuary in particular. They remain seated at the door of the holy sanctuary fully trusting in God. The climate here is very good, and there is no kind of contagious disease. In Medina the Radiant, many companions built hospices by way of perpetual charity. Most buildings are charitable endowments (waqf). Quite a few are rented out by the government, the income being deposited in the public treasury.

\footnotetext{
qAncient name for Medina.
} 


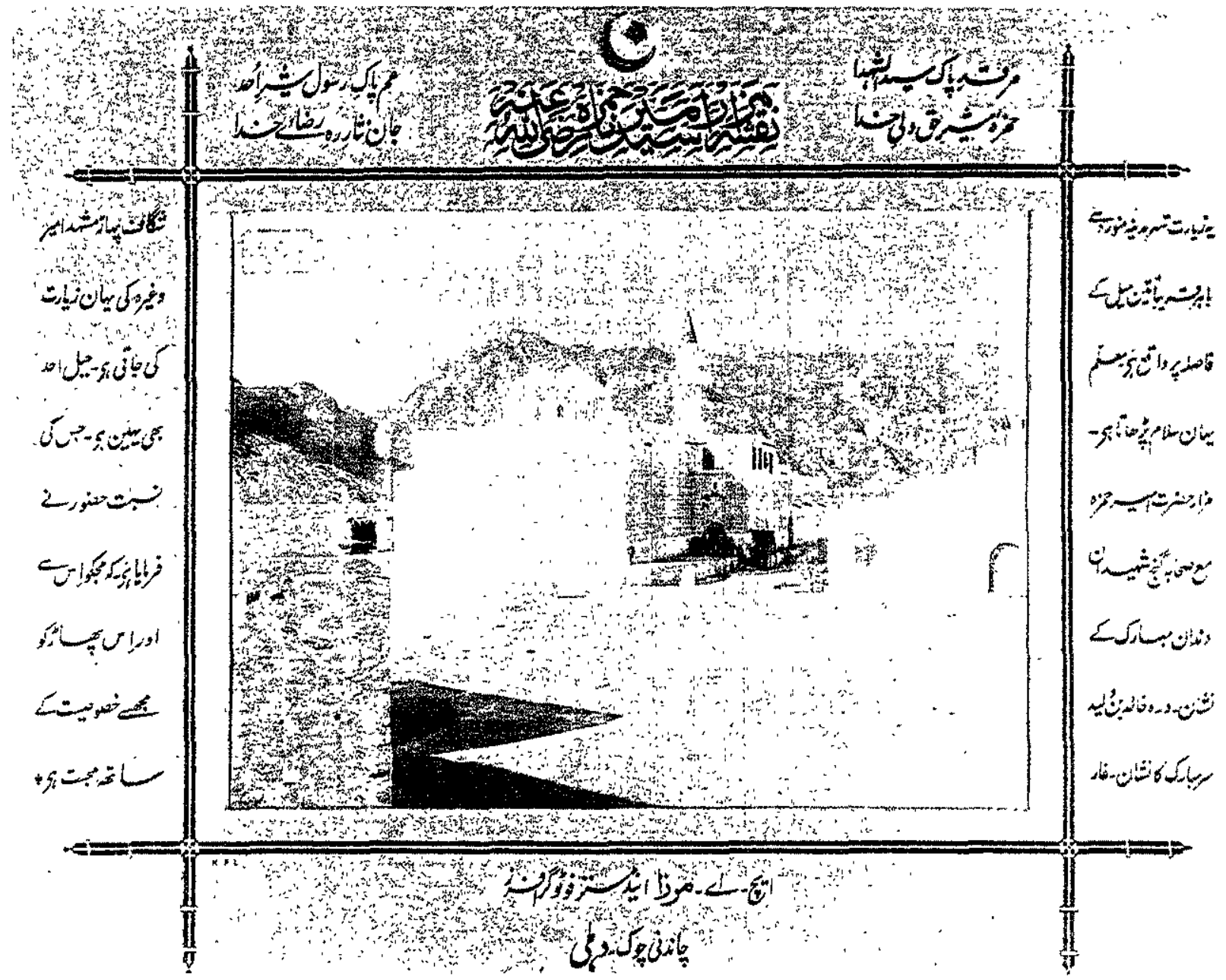

10. Picture of the Mausoleum of Our Lord Amir Hamza, ${ }^{r}$ May God Be Pleased upon Him

The sacred tomb of the lord of martyrs Hamza, the lion of Divine Truth and friend of God The holy uncle of the Prophet and the lion of [the battle of] Uhud.

Devotee of the path of God's will.

This pilgrimage site is located at a distance of approximately three miles from the city of Medina the Radiant. A guide-instructor here makes pilgrims recite the benedictions. Here takes place the pilgrimage to the mausoleum of Amir Hamza and the companions [of the Prophet], the treasury of martyrs, the relic of the blessed teeth, ${ }^{\mathrm{s}}$ the relic of the blessed head of Khalid ibn Walid,' the cave with the fissure, the mountain, the place of martyrdom of the Amir, and so on. Here also is Mount Uhud concerning which the Prophet has said, "I have toward it and the mountain has toward me a very special love."

'See above, note 11 .

'The Prophet apparently lost one or two of his teeth during the battle of Uhud.

${ }^{t} A$ general of the Muslim army, farned for his bravery; he died in 642.

"Mount Uhud enjoys this special reputation becausc of a cave there which sheltered the Prophet while he was being pursued by his enemies. 


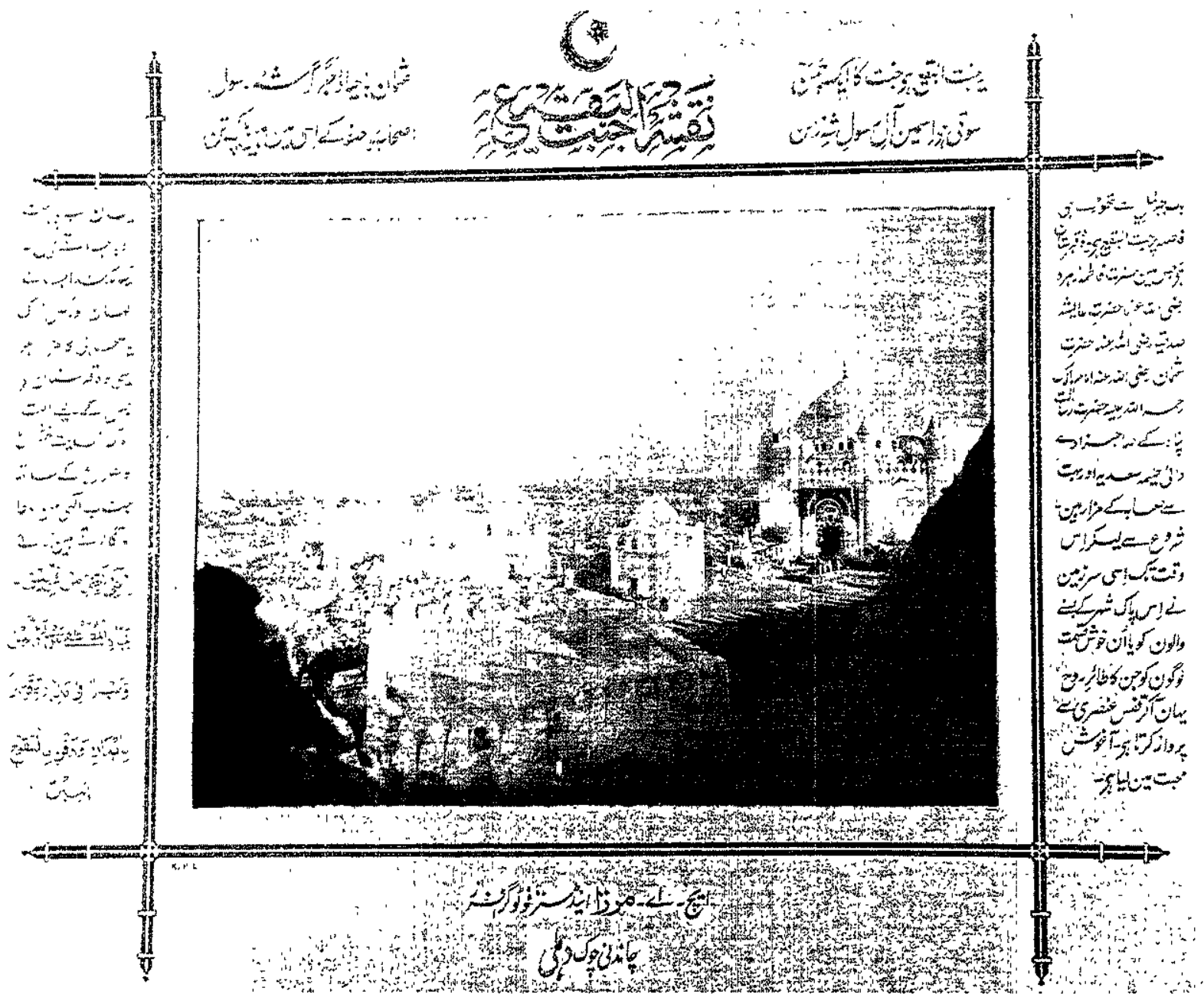

\section{Picture of the Paradise Garden of al-Baqi $\mathrm{i}^{\mathrm{C}}$}

This paradise garden of al-Baqi' is a meadow of Paradise;

Asleep within is the family of the Prophet, the lord of the age;

Also here are the holy bodies of "Uthman," the bashful, the darling of the Prophet and the companions pure.

A small distance from the Bab Jibril is the paradise garden of al-Baqi. It is the cemetery in which are tombs of Fatima ${ }^{\text {w }}$ the Resplendent, may God be pleased with her; 'Aisha ${ }^{x}$ the Sincere, may God be pleased with her; 'Uthman, may God be pleased with him; Imam Malik, y' may God have mercy on him, Halima, the fortunate, the noble-born wet-nurse of the refuge of apostleship and many other companions. From the beginning until now, this area has taken into loving embrace the in- habitants of this holy city and people whose soul birds have come here after having flown away from the cage of the elements [the body]. Here everyone moves around respectfully with the utmost care because God only knows where there may be a tomb belonging to some venerable person or companion [of the Prophet]. This is the cemetery for which most people pray to God, with utmost humility:

O God, save me from every affliction

By the honor of the chosen one, the lord of the beautiful [the Prophet]

And grant me in Medina firmness of faith and burial in al-Baqi. Amen.

"Uthman b. Aftan (d 656), the third caliph.

"Daughter of the Prophet, died 633.

"A favorite wife of the Prophet, died 678.

yalik ibn Anas (d. 795), founder of the Sunn Maliki school. 


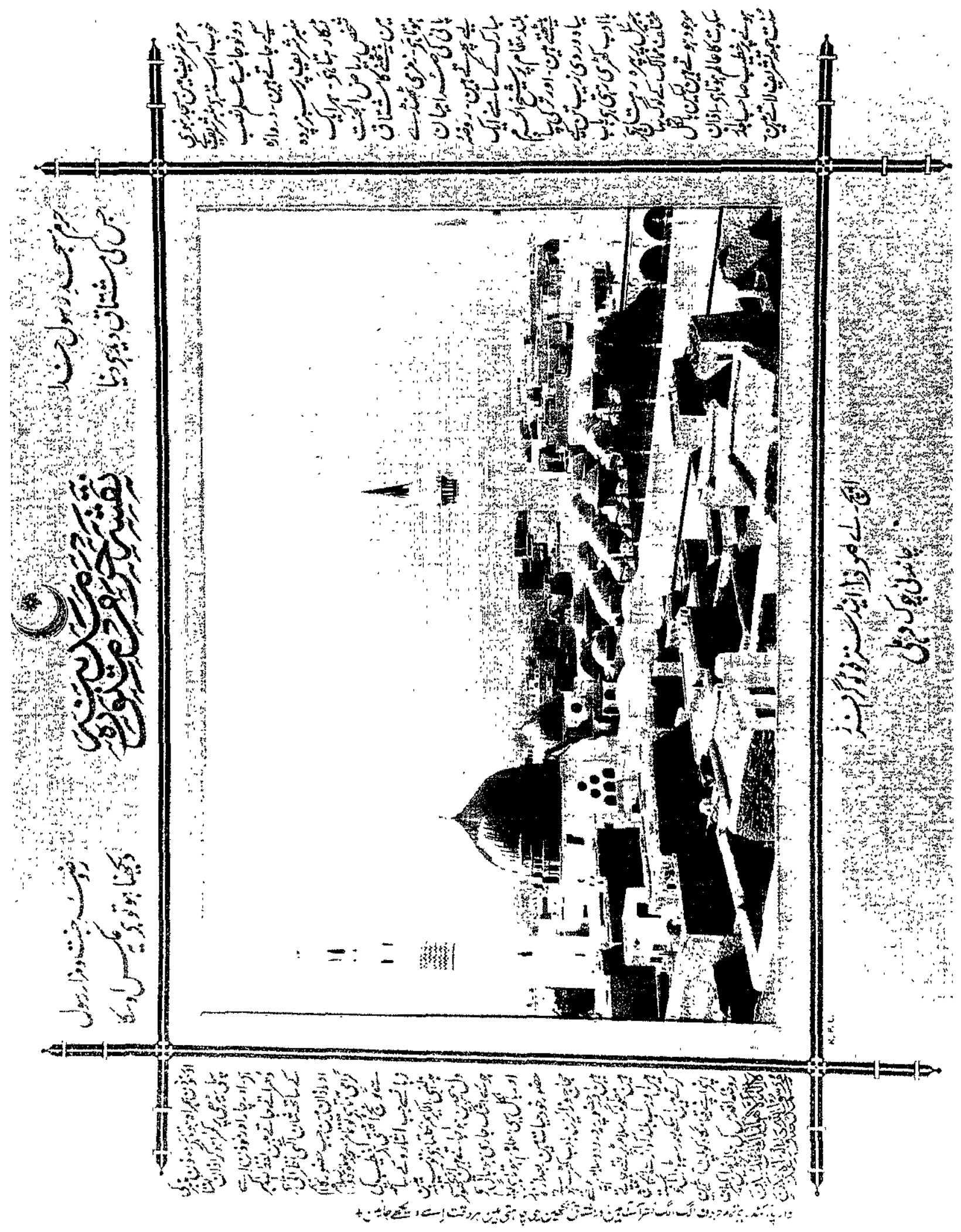


12. Picture of the Sanctuary of Medina the Radiant

The sanctuary of the mosque of the messenger of God

which the world yearns to see.

A garden of Paradise and the mausoleum of the Prophet;

If you must see it, here is its image.

Within the holy sanctuary, the Mosque of the Prophet is well adorned. On both sides of the holy pulpit flags have been set up. A green curtain hangs on the door of the pulpit. Everyone longs to sit in this garden of Paradise. They walk around with flasks of cold water from [the well of] Zamzam. In front of the blessed mausoleum, on a high stage, sits the shaikh of the sanctuary. Turkish soldiers in black and yellow uniform stand respectfully. At the Bab Jibril there is also a guard. Though people from different countries are present here, yet it is a world of complete silence. In accordance with the custom of the Prophet, on Fridays the preacher enters immediately after the call to prayer accompanied by the muezzin. The muezzin gives the call to prayer by standing on the first stair of the pulpit, four other muezzins repeat it after him. With [recitation of the] words, Allähu akbar, divine glory becomes manifest. When the venerable name of the Prophet occurs in the call to prayer, a tumult of prayers and blessings on the Prophet rises from the entire mosque. When the words, "This is the noble Prophet," come forth from the mouth of the preacher, hearts in breasts become restless and streams of tears begin to flow from the eyes. It entirely seems as if the Prophet himself were alive. After the prayer, the pilgrims and visitors [to the tomb] stand respectfully, reciting benedictions and blessings on the Prophet. The instructor guides continue reciting blessings, and all follow them in a loud voice. Then all return to their own places of residence with unwilling hearts. Engraved across one side of the lattices of the most sacred mausoleum: "There is no god but the Lord, the Truth, the Manifest; Muhammad, the one faithful to promise, the trustworthy, is the messenger of God." All the letters are visible individually, with desirous eyes yearning to see them all the time. 


\section{NOTES}

Authors' notc: We wish to thank Mr. Fouad César Debbas for graciously permitting us to publish the preservation photos of his album (FCD 83:006: 1-12), now in the Archives for Historscal Documentation (AHD). (Located in Brighton, Massachusetts, the AHD preserves and publishes on a non-profit basis previously inaccessible documents relating to the cultural history of the Middle East.) We would also like to thank Dr. M. J. Waley, head of Persian and Turkish Collections and $\mathrm{Mr}$ John Falconer at the Oriental and India Office Collections for their invaluable information on the parallel Mrra album in the British Library, Ms. Elizabeth Carella, for modern preservation photography and technical notes; Dr. Sami al-Angawi and Mr. Sabri Jarrar for information on the architectural history of the Hijaz.

1. The caption is from an Urdu guide to the pilgrimage, 'Abd al-Halìm Sāhil, Hajj Bait Alläh (Bombay' Khwaja Publishing House, 1968).

2. See Carney E. S. Gavin, "The Earliest Voices from the East: Phono-archaeological Explorations and Tomorrow's Museums," Museum 158 (1988): 68-69, and fig. 1. Because the Leiden photographs had been found in disarray, without discernible order among materials which had been moved at least four times from Wittesingel to Rappenburg to Nordendplein and finally to Wittesingel once again, the AHD suspects that Leiden's entire set of Mirza postcards may date to 1908 and Scheltema's collecting.

3. In H. Kazem Zadeh, Relation d'un pélerinage à la Mecque en 1910-191J (Paris: Ernst Leroux, 1912).

4. A powerful testament to the strong attachment that Indian pligrims felt towards the tombs in this cemetery occurs in Eldon Rutter's account of his visit to Mecca and Medina. When he visited the al-Baqi cemetery in 1925. he found that the Wahhabi iconoclastic zealots had razed many of the tombs to the ground so that it resembled a town demolsshed by an earthquake. As he approached the demolished tomb of 'Uthman (d. 656), the third caliph of Islam, he came across a party of Indian pilgrims whose leader had tears flowing from his eyes on account of the grief he felt from witnessing this wanton destruction. At the site of the tomb itself, he found a large-turbaned Indian chanting the Qur'an. Another sat near him, sobbing. Eldon Rutter. The Holy Catzes of Arabra, 2 vols. (London-New York G. P. Putnam's Sons, 1928), 2:258.

5. Cf. Frances W. Prichett, The Romance Tradution in Lrdu: Adventures from the Dastan of Amir Hamzah (New York: Columbia University Press, 1991).

6. See Carney E. S. Ciavin, "Messengers from Mecca: Photography and Social Studies In Light from Ancient Lands," The Invention of Photography and Its Impact on Learning, ed. L. T. Ambler and M. Banta (Cambridge, Mass.: Harvard University Library, 1989), pp. 48-6 J. AHD is preparing a short biography of the extraordinary accomplishments of General M. Sadic Pasha whose achievements (which included a medal at the U.S. Centennial Exposition in 1876) may have escaped subsequent acclamation partly because of the nonchalance with which he spelled his family name: Sadic he seems to have favored for handwriting, but he also used Sadiq and Sadik-and sometimes all three spellings in the same docu- ment. Because the general was a colonel in 1880 , he appends the honorific "Bey" to each spelling of his name, Sadic/ $\mathrm{k} / \mathrm{q}$ A skilled mapmaker who had studied the tribes and caravan routes of the Hijaz, he eventually became the president of the Khedival Geographical Socrety to which hc devoted the final years of his life after retirement from the army as liwo (lieutenant general).

7. By d'-Sayvid 'Abd al-Ghaffar, published as plate 10 in C. Snouck Hurgronje, Bilder aus Mekka (Leiden: E. J. Brill, 1889).

8. Richard Ettinghausen, "Die bildliche Darstellung der Ka ${ }^{c} \mathrm{ba}$ in Islamischen Kulturkreis," Zeitschrift der Deutschen Morgenlärdischen Gesellschaft 87, no. 3-4 (1934): 116. The Armenian Ignatius Mouradgea d'Ohsson who traveled extensively in the Ottoman Empire in the late eighteenth century records that upper-class residents in Istanbul were "accustomed to keep in their houses little pictures of the Ka' ba and the Prophet's tomb - the glory of Arabian cities" (Tableau general de l'Empire othoman (Paris, 1787-1820), vol. 4, pt. 2, pp. 461 .

9. Cf. Hasan al-Basha, "Ottoman Pictures of the Mosque of the Prophet in Madina as Historical and Documentary Sources," Islamic Arts 4 (1989): 227-43.

10. In 1868 photographs had been used for the first time to illustrate a hail account published in Urdu, but the description of the pilgrimage in 1864 by the Begum of the kingdom of Bhopal does not, however, contain any photographs of religious sites; instead it features officials and scenes at Her Highness's court.

11. H. A. Mirza appears to have been the fourth to have published pictorial reports of the holy cities. The first was Muhammad Sadic (see above n. 6), who with the permission of Sharif Aun al-Rafiq made the first photographs of Medina and Mecca in 1880. In 1889, C. Snouck Hurgronje, at the outset of his career as a colonial-service officer, published two photographic collections on Mecca. In the first, Bilderatlas, published in The Hague by Martinus Nijhoff as an unbound portfolio of illustrations to accompany his twovolume work, Mekka, he included reproductions in lithographic form of panoramas photographed by Sadiq Bey with appropriate acknowledgments. In Bilder aus Mekka, his second album, published in Lerden by E.J. Brill, Hurgronje chose to mention only his own name and to erase the name of the actual photographer Sayyid Abd al-Ghaffar, the geographic annotations he had written on the orignnal glass plates, and his elegantly calligraphed signature. The actual photographer was first identified by Frederick H. S. Allen and Carney E. S. Gavin in Mecca, the First Photographs (Cambridge, Mass.: Harvard Semitıc Museum and J. P. Morgan, Inc., 1981). 'Abd al-Ghaffar was a skilled opthalmologist as well as a brilliant photographer; his scores of still unpublished portraits of Makkawis (often posed with their children) are among the most lively family pictures produced in the nineteenth century. Intriguingly, Hurgronje seems not even to have recognized the contiguity of "Abd al-Ghaffar's multi-part panoramic views of Mecca. The quality of 'Abd al-Ghaffar's lens work brilliantly preserves the city's original character in such tantalizingly crisp detail that we can study even the intricate arrangements of the glazed-brick ventilating screens $(a j j u l)$ which decorously segregate roof- 
tops regularly rented out by house owners to pilgrims as slecping arcas.

12. Snouck Hurgronje notes that a religious treatise by a Meccan sheikh printed in 1882 warns against the inroads on piety that "unlawful usages and infidel culture" were making, particularly the use of pictures: "Among the things that lead into Hell is that the devils in these times have put into the heads of the Christians and other God-abandoned people to place on all wares that are used by man pictures of living creatures so that there is hardly a house, shop, market. bath. fortress, or ship without pictures ... even into our mosques pictures come, for most people, when they come to prayer, have with them little packets of cigarettes and tobacco on which there are pictures; so I warn you, O brethren!" (Mekka in the Latter Part of the 19th Century: Dally Life, Customs and Learning of the Moslims of the East Indian Archipelago, trans. J. H. Monahan [Leiden and London: E. J. Brill and Luzac \& Co.. 1931], p. 165. For a more contemporary example. the influential South Asian religious scholar Abu'l A'la Maududı (d. 1979) issued a religious edict against photography (and any other future technology that might create realistic images) on the grounds that it was corrupting society. He permitted it only for limited practical uses, for example by the government for passport photographs. He also told a photographer that out of fear of God he should change his profession (Ishãq Sandhelvî and Maulänã Abū'l Álã Maudūdī, Tasvir: 'ìlm o 'aql kī raushanì meñ (Hyderabad: Maktaba-i Nishat-i Thaniyya. n.p., [1964?]), p. 55.

13. Cf. Michael N. Pearson's comments. "My own acquaintance with some of them [Indian pilgrims] leads me to suspect that the pilgrims are also programmed what to feel. They feel awe and fear in Mecca, love in Medina and so on, simply because this is what they know is expected of them" (Pilgrmage to Mecca, The Indian Experience 1500-1800 (Princeton, N.J.: Markus Wiener), p. 9.

14. They were apparently not alone in their experiment, for an Egyptian contemporary, Ibrahim Rif at Pasha (1857-1936), had also discovered the usefulness of photography as an instrument of piety: he recorded the pilgrimages of 1903 , 1904, and 1908. His photographs, however, served a secondary role as illustrations to his book, Mir'at al-Haramayn, published in Cairo by the National Library Press in 1925. See Gavin. "Photography and Social Sciences," pp. 52-53.

15. Barbara Metcalf, "The Pilgrimage Remembered: South Asian Accounts of the Haij," in Muslim Travelers, Pilgrimage, Migration and the Religzous Imagination, ed. Dale Eickelman and James Piscatori (Berkeley and Los Angeles: University of California Press, 1990), p. 95.

16. 'Abd al-Halim Sāhịi, Haj̉ Bant Allah, p. 240. 